\title{
Characteristics of Heavy Metals and Pb Isotopic Composition in Sediments Collected from the Tributaries in Three Gorges Reservoir, China
}

\author{
Bo Gao, ${ }^{1,2}$ Huaidong Zhou, ${ }^{1,2}$ Yong Huang, ${ }^{3}$ Yuchun Wang, ${ }^{1,2}$ Jijun Gao, ${ }^{1}$ and Xiaobo Liu ${ }^{1}$ \\ ${ }^{1}$ Department of Water Environment, China Institute of Water Resources and Hydropower Research, Beijing 100038, China \\ ${ }^{2}$ State Key Laboratory of Simulation and Regulation of Water Cycle in River Basin, China Institute of Water Resources and \\ Hydropower Research, Beijing 100038, China \\ ${ }^{3}$ College of Horticulture, Jilin Agricultural University, Changchun 130118, China
}

Correspondence should be addressed to Bo Gao; gaosky34@hotmail.com and Huaidong Zhou; hdzhou@iwhr.com

Received 27 August 2013; Accepted 19 October 2013; Published 28 January 2014

Academic Editors: J. Lutzenkirchen and G. Sen

Copyright $\odot 2014$ Bo Gao et al. This is an open access article distributed under the Creative Commons Attribution License, which permits unrestricted use, distribution, and reproduction in any medium, provided the original work is properly cited.

\begin{abstract}
The concentrations, distribution, accumulation, and potential ecological risk of heavy metals $(\mathrm{Cr}, \mathrm{Cu}, \mathrm{Zn}, \mathrm{Ni}, \mathrm{As}, \mathrm{Pb}, \mathrm{Cd}$, and $\mathrm{Hg}$ ) in sediments from the Three Gorges Reservoir (TGR) tributaries were determined and studied. Pb isotopic compositions in sediments were also measured to effectively identify the potential $\mathrm{Pb}$ sources. The results showed that the average concentrations of heavy metals in sediment of TGR tributaries were higher than the local background values of soils and sediments in China. The assessment by Geoaccumulation Index indicated that $\mathrm{Cu}, \mathrm{Ni}$, and $\mathrm{Hg}$ were at the "slightly polluted" level and $\mathrm{Cd}$ was ranked as the "moderately polluted" level in tributary sediments of TGR. The assessment by Potential Ecological Risk Index showed that Hg and $\mathrm{Cd}$ were the predominant elements in tributary sediments in TGR. The $\mathrm{Pb}$ isotopic ratios in sediments varied from 1.171 to 1.202 for ${ }^{206} \mathrm{~Pb} /{ }^{207} \mathrm{~Pb}$ and from 2.459 to 2.482 for ${ }^{208} \mathrm{~Pb} /{ }^{207} \mathrm{~Pb}$ in TGR. All $\mathrm{Pb}$ isotopic ratios in sediments were similar to those from coal combustion, lead ores (the mining activities and smelting process), and cement material, indicating that these anthropogenic inputs may be the main sources for Pb pollution in sediments of TGR tributaries.
\end{abstract}

\section{Introduction}

In recent years, a large number of heavy metals were discharged into the nature environment because of anthropogenic activity such as ore mining, metal smelting, fossil oil burning, and machinery wearing. This can give rise to the accumulation of heavy metals in various environment media $[1,2]$. Sediment, as an important part in the water environment, is more and more important to study heavy metals pollution in rivers because it was often regarded as major indicator to assess the heavy metal pollution in water environment. In fact, heavy metals in sediments can be released into water when water chemical and hydrological condition changed [3]. Therefore, heavy metals in sediments can pose a threat to the water quality safety and aquatic organisms $[4,5]$.

The Three Gorges Dam, in China, is the world's largest dam with $2335 \mathrm{~m}$ length and $185 \mathrm{~m}$ height. With the completion of the Three Gorges Dam (2003), the Three Gorges Reser- voir (TGR) became the biggest reservoir in China, creating a total area of $1080 \mathrm{~km}^{2}$ in 2009 . The water level of the reservoir fluctuation resulted in the formation of the water-level-fluctuation zone with a total area of $350 \mathrm{~km}^{2}$ in the reservoir. The TGR plays important role in economic development and national drinking water safety.

However, how a dam impacts the local environment in TGR is still unknown. There is also little information available about the characteristic of heavy metals in the sediments in this huge reservoir, especially for the period of its submergence. Increased shipping and industrial waste will influence the deposition of heavy metals which have been accumulating in the water-level-fluctuation during submergence period. In the downstream of the reservoir, intensive land use has also increased nonpoint pollutants in the reservoir region. The primary objectives of the present study were (1) to provide basic information of the concentration and distribution of the 
heavy metal contamination in sediments of TGR tributaries after the submergence, (2) to perform sediment pollution assessment using the Geoaccumulation Index $\left(I_{\text {geo }}\right)$ and the Potential Ecological Index, and (3) to trace the sources of $\mathrm{Pb}$ pollution in sediments using $\mathrm{Pb}$ isotopic ratios. This study provides relevant information of the heavy metal contamination in tributary sediments of TGR after the submergence. These data will form the basis for the comparison with future data related to heavy metal pollution in sediments and be useful for the development of management decisions, pollution-control, and sediment remediation strategies in this region.

\section{Materials and Methods}

2.1. Sample Sites. The tributary sediments were collected from the TGR, China. A map of the sampling locations is shown in Figure 1. The TGR area is located in China, west of Hubei and east of Chongqing city $\left(28^{\circ} 32^{\prime}-31^{\circ} 44^{\prime} \mathrm{N}\right.$ and $105^{\circ} 44^{\prime}-111^{\circ} 39^{\prime} \mathrm{E}$ ), covering an overall area of $58,000 \mathrm{~km}^{2}$ and including totally 20 districts and counties (cities). TGR is the largest hydroelectric project ever built in China, as well as in the world. After the Three Gorges Dam was constructed at Sandouping, a large dam formed in the upstream direction of the Yangtze River, with the length of over $600 \mathrm{~km}$. The reservoir waters and their fringe areas are generally called the TGR area of the Yangtze River.

2.2. Sample Collection. Twenty-six surface sediments (two samples for each tributary) were collected from thirteen major tributaries of TGR in March 2009 after its submergence period. The sampling tributaries were described within the zone (Figure 1). At each sampling site, sediment samples were taken using a stainless steel collector near the middle of the flow of the stream. About $1 \mathrm{~kg}$ of sediments was collected into clean polyethylene bags and treated immediately on returning to the laboratory. The sediment samples were wetsieved through an acid-cleaned $63 \mu \mathrm{m}$ mesh nylon sieve in order to obtain the chemically active material, dried at $-40^{\circ} \mathrm{C}$ to constant weight, and ground in an agate mortar to ensure homogeneity.

2.3. Analytical Methods. All chemical treatments were in the ultraclean laboratory, and all reagents were of high purity grade. Total metal concentrations in the sediments were measured using the established method [6]. Briefly, a mass of $40 \mathrm{mg}$ of dry sample was weighed and dissolved into $10 \mathrm{~mL}$ Teflon bombs. About $2 \mathrm{~mL}$ concentrated $\mathrm{HNO}_{3}+0.2 \mathrm{~mL}$ concentrated $\mathrm{H}_{2} \mathrm{O}_{2}$ were added to samples and left on a hot plate for one day. This step was to remove organic materials from sediment samples. The samples were then dried at $120^{\circ} \mathrm{C}$. The residue was dissolved in $1 \mathrm{~mL} \mathrm{HNO}_{3}+1 \mathrm{~mL} \mathrm{HF}$ of samples. After $30 \mathrm{~min}$ ultrasonic procedure, the samples were taken into sealed bombs and were placed in an oven at $190^{\circ} \mathrm{C}$ for $48 \mathrm{~h}$. This procedure resulted in clear solutions for sediment sample. After evaporation at $120^{\circ} \mathrm{C}$, samples were dissolved in $1 \% \mathrm{HNO}_{3}$. Inductively coupled plasmamass spectrometry (ICP-MS, Perkin Elmer Elan DRC-e) was used to determine the total concentration of $\mathrm{Cd}, \mathrm{Cr}, \mathrm{Cu}, \mathrm{Ni}$, $\mathrm{Pb}, \mathrm{As}$, and $\mathrm{Zn}$. Mercury in sediments was determined by the Direct Mercury Analyzer (Milestone DMA-80). The accuracy of the analytical procedures employed for the analysis of the metals in sediments was checked using the certified China reference material of stream sediment (GSD-12, GBW07312), obtaining good agreement with certified values.

2.4. Pb Isotopic Measurement. Pb isotopic analyses were separated using microexchange columns of anion resin of Dowex-I (200-400 mesh) and $\mathrm{HBr}$ and $\mathrm{HCl}$ as eluants [7]. Measurements of $\mathrm{Pb}$ isotopic compositions were carried out using a VG-354 mass spectrometer. The average measured values of the standard NIST SRM-981 are ${ }^{206} \mathrm{~Pb} /{ }^{204} \mathrm{~Pb}=$ $16.934 \pm 0.007,{ }^{207} \mathrm{~Pb} /{ }^{204} \mathrm{~Pb}=15.486 \pm 0.012$, and ${ }^{208} \mathrm{~Pb} /$ ${ }^{204} \mathrm{~Pb}=36.673 \pm 0.033(n=20)$, respectively, which are in good agreement with the recalibrated values of 16.9322 , 15.4855, and 36.6856, respectively [8]. Analytical uncertainties in $2 \mathrm{~s}$ ( $2 \mathrm{~s}, 2$ standard deviation) for $\mathrm{Pb}$ isotopic ratios were better than $0.1 \%$.

2.5. Assessment Methods. The Geoaccumulation Index $\left(I_{\text {geo }}\right)$ introduced by Müller (1979) was used to assess metal pollution in sediments [9]. Geoaccumulation Index is expressed as follows:

$$
I_{\text {geo }}=\log _{2}\left(\frac{C_{n}}{1.5 B_{n}}\right),
$$

where $C_{n}$ is the measured concentration of heavy metal $(n)$ in the sediment, $B_{n}$ is the geochemical background value of heavy metal $(n)$, and 1.5 is the background matrix correction factor due to lithogenic effects. In the present study, $B_{n}$ was selected from the literature [10]. Geoaccumulation Index includes seven grades from Class $0\left(I_{\text {geo }} \leq 0\right)$ to Class 6 $\left(I_{\text {geo }} \geq 5\right)$ in Table 1 .

The Potential Ecological Risk Index introduced by Häkanson was also used to assess potential ecological risk of heavy metals in sediments [11]. The Potential Ecological Risk Index (RI and $E_{i}$ ) is expressed as follows:

$$
\begin{gathered}
E_{i}=T_{i}\left(\frac{C_{i}}{C_{i}^{n}}\right), \\
\mathrm{RI}=\sum E_{i}=\sum T_{i}\left(\frac{C_{i}}{C_{i}^{n}}\right),
\end{gathered}
$$

where $C_{i}$ is the measured concentration of heavy metal (i), $C_{i}^{n}$ is the geochemical background value of heavy metal $(i)$, and $T_{i}$ is the toxic coefficient of heavy metal $(i)$. In this study, the toxic coefficients of $\mathrm{Cr}, \mathrm{Cu}, \mathrm{Zn}, \mathrm{Ni}, \mathrm{As}, \mathrm{Pb}, \mathrm{Cd}$, and $\mathrm{Hg}$ are $2,5,1,5,10,5,30$, and 40 , respectively [12]. The potential ecological risk degree is shown in Table 2.

\section{Results and Discussion}

3.1. Concentrations of Heavy Metals in Sediments. The results of heavy metal concentrations in sediments of TGR tributaries are shown in Table 3. The mean concentrations of $\mathrm{Cr}$, 


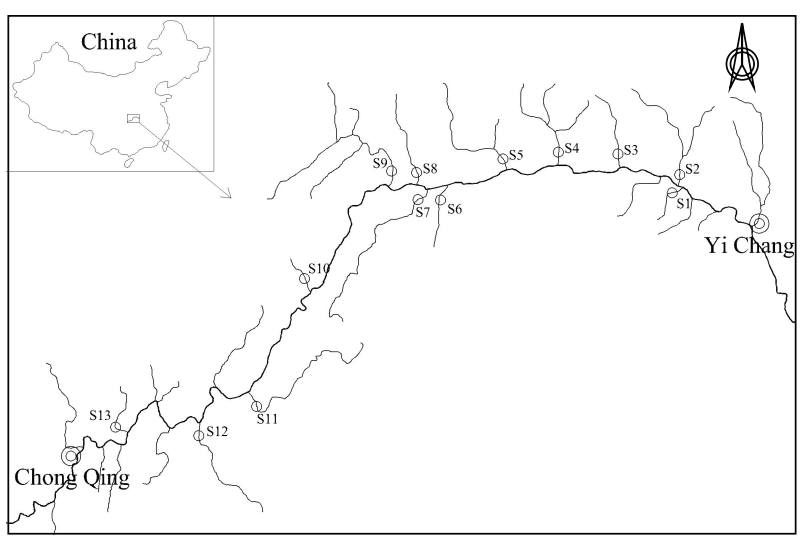

(2) City

- Sample site

FIGURE 1: Map of the study area and sampling sites in TGR.

TABLE 1: Geoaccumulation Index and classification of pollution degree.

\begin{tabular}{lcc}
\hline$I_{\text {geo }}$ value & Classification & Pollution level \\
\hline$<0$ & 0 & Unpolluted \\
$0 \sim 1$ & 1 & Slightly polluted \\
$1 \sim 2$ & 2 & Moderately polluted \\
$2 \sim 3$ & 3 & Moderately to strongly polluted \\
$3 \sim 4$ & 4 & Strongly polluted \\
$4 \sim 5$ & 5 & Strongly to extremely polluted \\
$>5$ & 6 & Extremely polluted \\
\hline
\end{tabular}

$\mathrm{Cu}, \mathrm{Zn}, \mathrm{Ni}, \mathrm{As}, \mathrm{Pb}, \mathrm{Cd}$, and $\mathrm{Hg}$ in sediments in TGR were $79.73,46.67,114.79,41.67,12.26,38.11,0.71$, and $0.13 \mathrm{mg} / \mathrm{kg}$, respectively. The mean of the heavy metals in sediments from TGR was significantly higher than the background values of soils and sediment $[10,13]$. This indicated that the sediments in TGR may be contaminated by heavy metals from anthropogenic sources. In fact, the minimum concentrations of the metals including $\mathrm{Cr}, \mathrm{Cu}, \mathrm{Ni}$, and $\mathrm{Cd}$ were also higher than the soils background values in China. The order of heavy metals in sediments of TGR tributaries was $\mathrm{Zn}>\mathrm{Cr}>\mathrm{Cu}$ $>\mathrm{Ni}>\mathrm{Pb}>\mathrm{As}>\mathrm{Cd}>\mathrm{Hg}$. Since China government does not have its own regulatory guideline for sediments, probable effects concentration (PEC) and threshold effect concentration (TEC) [16] were used to assess the ecotoxicological level of observed metal levels. The mean concentrations of $\mathrm{Cd}, \mathrm{Zn}$, and $\mathrm{Hg}$ in sediments of TGR tributaries were lower than TEC values, indicating that these metals were unlikely to result in harmful effects. However, sediments samples with the mean concentration of other metals between PEC and TEC may be toxic for aquatic organism. Heavy metals concentrations in sediments of other Chinese rivers were also presented in Table 3. It can be seen that the concentrations of heavy metals in sediments of TGR tributaries were generally lower than the downstream in Yangtze River. This result may be attributed to the differences of geographical characteristic, industrial development in the downstream of Yangtze River, especially for the high-speed development of large cities. In fact, several Chinese larger cities are located in the downstream of Yangtze River, such as Wuhan, Shanghai, and Nanjing. In addition, since the TGR was in the upstream of Yangtze River, heavy metals in sediments or suspended particles can be transferred from the upstream to downstream with the water flowing in Yangtze River.

3.2. Spatial Distribution of Heavy Metals in Sediments. From Figure 2 (Cd and $\mathrm{Hg}$ concentrations were 50 times the actual concentrations to better comparison with other metals), it can be seen that the mean concentrations of $\mathrm{Cr}, \mathrm{Cu}, \mathrm{Ni}$, $\mathrm{As}, \mathrm{Pb}$, and $\mathrm{Hg}$ in midstream (including from S5 to $\mathrm{S} 10$ ) of TGR were generally higher than those in downstream (including from S1 to S4), and the lowest value of these metals was located in upstream (including from S11 to S13), as in Figure 1. But the order of the mean concentrations of $\mathrm{Zn}$ and $\mathrm{Cd}$ was downstream $>$ midstream $>$ upstream. This indicated that the contaminations of $\mathrm{Zn}$ and $\mathrm{Cd}$ were more seriously in upstream. The heavy metals in sediments from TGR tributaries showed a similar spatial distribution, except for $\mathrm{Zn}$ and $\mathrm{Cd}$. Among tributaries of TGR, the highest value of $\mathrm{Zn}$ and $\mathrm{Cd}$ were observed at site S2 (XiangXi River). In addition, the highest concentrations of $\mathrm{Cr}, \mathrm{Cu}, \mathrm{Ni}, \mathrm{As}$, and $\mathrm{Pb}$ were found in S7 (the tributary of Modao River), and the highest concentration of $\mathrm{Hg}$ was observed at S10 (Ruxi River).

3.3. The Correlation among Heavy Metals in Sediments. To explore the geochemical behaviors of heavy metals in surface sediments from TGR tributaries, the correlations among heavy metals in sediments are presented in Table 4. In fact, $\mathrm{Hg}$ showed an obvious correlation with other elements in sediments, suggesting that $\mathrm{Hg}$ possibly existed at various pollutants. There were significant correlation coefficients among $\mathrm{Cr}, \mathrm{Cu}, \mathrm{Zn}, \mathrm{As}$, and $\mathrm{Cd}$ in sediments, suggesting that they may have similar pollution sources. In addition, $\mathrm{Pb}$ showed only obvious correlations with $\mathrm{Ni}$, demonstrating that these two metals have common sources in sediments. According to the previous studies of heavy metals, the pollution sources of heavy metals may be complicated from several sources $[17,18]$. In this present study, the main pollution sources may be industrial pollution especially for smelting metal and fuel combustion.

3.4. Pollution Assessment. The results of the $I_{\text {geo }}$ values and pollution level of heavy metals of sediments in TGR tributaries were shown in Table 5. In the sediments of TGR tributaries, the average $I_{\text {geo }}$ values of $\mathrm{Cr}, \mathrm{Cu}, \mathrm{Zn}, \mathrm{Ni}, \mathrm{As}, \mathrm{Pb}$, $\mathrm{Cd}$, and $\mathrm{Hg}$ are $-0.21,0.29,-0.06,0.02,-0.49,-0.17,1.99$, and 0.27 , respectively. Distinctly, the average $I_{\text {geo }}$ value of Cd was significantly higher than other metals in the sediments, which was ranked as "moderately polluted" level. The highest contamination level of Cd was observed in sampling sites of S2, which was ranked as "strongly to extremely polluted" level. In addition, the average $I_{\text {geo }}$ of $\mathrm{Cu}, \mathrm{Ni}$, and $\mathrm{Hg}$ was lower than 1 , which was ranked as "slightly polluted" level. In detail, the $I_{\text {geo }}$ values of $\mathrm{Cu}$ and $\mathrm{Hg}$ in sampling sites such as S5, S7, and S10 were more than 1, which was ranked as "moderately 


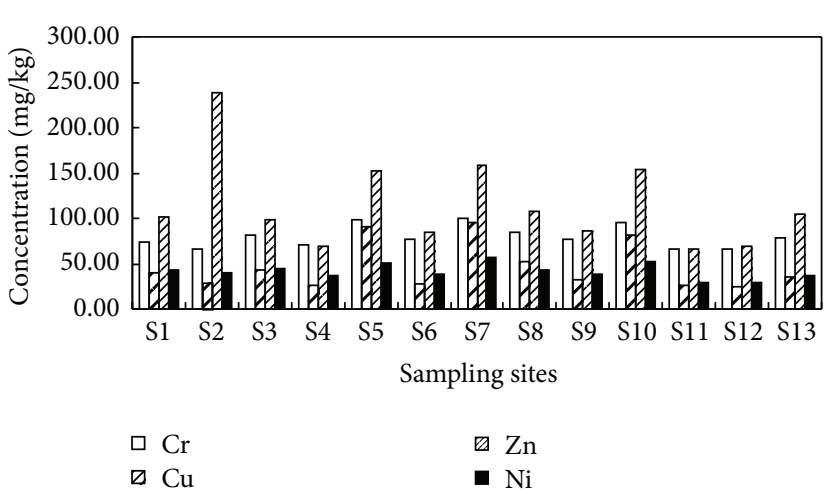

(a)

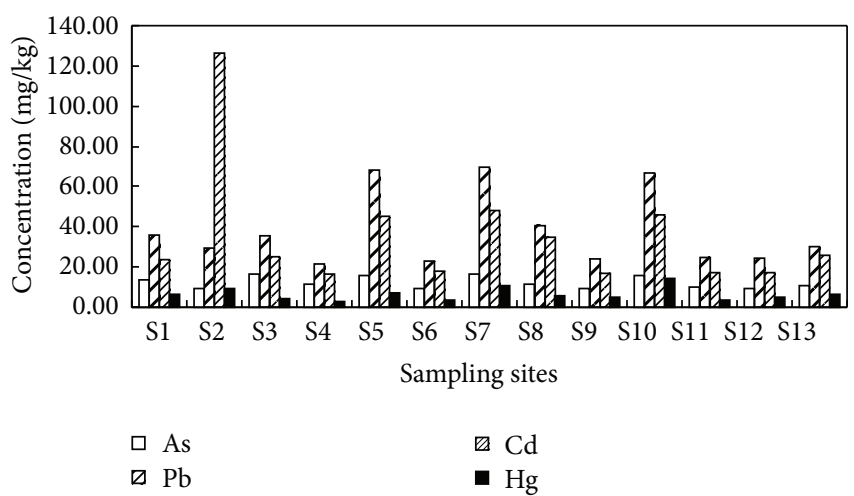

(b)

FIGURE 2: Spatial distribution of heavy metals in sediments from TGR tributaries.

TABLE 2: Description of potential ecological risk degree.

\begin{tabular}{lccc}
\hline$E_{i}$ & Ecological risk of single metal & RI & Ecological risk of all metals \\
\hline$E_{i}<40$ & Slightly & RI $<150$ & Slightly \\
$40 \leq E_{i}<80$ & Moderately & $150 \leq \mathrm{RI}<300$ & Moderately \\
$80 \leq E_{i}<160$ & Strongly & $300 \leq \mathrm{RI}<600$ & Strongly \\
$160 \leq E_{i}<320$ & very strongly & $600 \leq \mathrm{RI}$ & Very strongly \\
$320 \leq E_{i}$ & Extremely & & \\
\hline
\end{tabular}

TABLE 3: The levels of heavy metals in surface sediments from TGR tributaries and other rivers in China.

\begin{tabular}{|c|c|c|c|c|c|c|c|c|c|}
\hline \multirow{2}{*}{ Location } & \multicolumn{8}{|c|}{ Chemical element } & \multirow{2}{*}{ Reference } \\
\hline & $\mathrm{Cr}$ & $\mathrm{Cu}$ & $\mathrm{Zn}$ & $\mathrm{Ni}$ & As & $\mathrm{Pb}$ & $\mathrm{Cd}$ & $\mathrm{Hg}$ & \\
\hline \multicolumn{10}{|l|}{ TGR } \\
\hline Max. & 99.92 & 95.18 & 238.73 & 57.24 & 16.65 & 69.96 & 2.52 & 0.29 & \multirow{3}{*}{ This study } \\
\hline Min. & 65.93 & 25.07 & 66.92 & 29.72 & 9.14 & 21.21 & 0.33 & 0.06 & \\
\hline Mean & 79.73 & 46.67 & 104.28 & 41.67 & 12.26 & 38.11 & 0.71 & 0.13 & \\
\hline Soil background values & 61.0 & 22.6 & 74.2 & 26.9 & 11.2 & 26.0 & 0.097 & 0.065 & {$[10]$} \\
\hline Sediment background & 82.0 & 35.0 & 78.0 & 33.0 & 9.6 & 27.0 & 0.3 & 0.08 & {$[13]$} \\
\hline Yangtze River (Wuhan) & 87.82 & 51.64 & 140.27 & 40.91 & 15.85 & 45.18 & 1.53 & 0.15 & {$[14]$} \\
\hline Lower reach of Yangtze River & 98.32 & 48.61 & 129.73 & 41.49 & 13.54 & 50.77 & 2.82 & 0.16 & {$[15]$} \\
\hline TEC & 43.4 & 31.6 & 121.0 & 22.7 & 9.8 & 35.8 & 1.0 & 0.18 & {$[16]$} \\
\hline PEC & 111.0 & 149.0 & 459.0 & 48.6 & 33.0 & 128.0 & 5.0 & 1.06 & {$[16]$} \\
\hline
\end{tabular}

TABLE 4: Analysis of correlation about heavy metals in surface sediments from TGR tributaries.

\begin{tabular}{|c|c|c|c|c|c|c|c|c|}
\hline Element & $\mathrm{Cr}$ & $\mathrm{Cu}$ & $\mathrm{Zn}$ & $\mathrm{Ni}$ & As & $\mathrm{Pb}$ & $\mathrm{Cd}$ & $\overline{\mathrm{Hg}}$ \\
\hline $\mathrm{Cr}$ & 1 & & & & & & & \\
\hline $\mathrm{Cu}$ & $0.922^{\mathrm{a}}$ & 1 & & & & & & \\
\hline $\mathrm{Zn}$ & $0.960^{\mathrm{a}}$ & $0.924^{\mathrm{a}}$ & 1 & & & & & \\
\hline $\mathrm{Ni}$ & 0.333 & 0.546 & 0.462 & 1 & & & & \\
\hline As & $0.823^{\mathrm{a}}$ & $0.853^{\mathrm{a}}$ & $0.846^{\mathrm{a}}$ & 0.282 & 1 & & & \\
\hline $\mathrm{Pb}$ & 0.040 & 0.281 & 0.189 & $0.948^{\mathrm{a}}$ & 0.030 & 1 & & \\
\hline $\mathrm{Cd}$ & $0.926^{\mathrm{a}}$ & $0.907^{\mathrm{a}}$ & $0.990^{\mathrm{b}}$ & 0.519 & $0.848^{\mathrm{a}}$ & 0.256 & 1 & \\
\hline $\mathrm{Hg}$ & $0.625^{\mathrm{b}}$ & $0.735^{\mathrm{a}}$ & $0.727^{\mathrm{a}}$ & $0.737^{\mathrm{a}}$ & $0.562^{\mathrm{b}}$ & $0.559^{\mathrm{b}}$ & $0.785^{\mathrm{a}}$ & 1 \\
\hline
\end{tabular}

${ }^{a}$ Correlation is significant at the 0.01 level (2-tailed).

${ }^{\mathrm{b}}$ Correlation is significant at the 0.05 level (2-tailed). 
TABLE 5: The Geoaccumulation Index and classification of heavy metals in sediments from TGR tributaries.

\begin{tabular}{|c|c|c|c|c|c|c|c|c|}
\hline \multirow{2}{*}{ Sampling site } & \multicolumn{8}{|c|}{$I_{\text {geo }}$ value/classification } \\
\hline & $\mathrm{Cr}$ & $\mathrm{Cu}$ & $\mathrm{Zn}$ & $\mathrm{Ni}$ & As & $\mathrm{Pb}$ & $\mathrm{Cd}$ & $\mathrm{Hg}$ \\
\hline S1 & $-0.29 / 0$ & $0.25 / 1$ & $-0.14 / 0$ & $0.08 / 1$ & $-0.31 / 0$ & $-0.13 / 0$ & $1.70 / 2$ & $0.39 / 1$ \\
\hline S2 & $-0.47 / 0$ & $-0.23 / 0$ & $1.10 / 2$ & $-0.04 / 0$ & $-0.87 / 0$ & $-0.40 / 0$ & $4.12 / 5$ & $0.92 / 1$ \\
\hline S3 & $-0.17 / 0$ & $0.36 / 1$ & $-0.17 / 0$ & $0.13 / 1$ & $-0.05 / 0$ & $-0.13 / 0$ & $1.77 / 2$ & $-0.08 / 0$ \\
\hline S4 & $-0.37 / 0$ & $-0.34 / 0$ & $-0.69 / 0$ & $-0.12 / 0$ & $-0.57 / 0$ & $-0.88 / 0$ & $1.16 / 2$ & $-0.68 / 0$ \\
\hline S5 & $0.11 / 1$ & $1.41 / 2$ & $0.45 / 1$ & $0.34 / 1$ & $-0.07 / 0$ & $0.81 / 1$ & $2.64 / 3$ & $0.59 / 1$ \\
\hline S6 & $-0.26 / 0$ & $-0.26 / 0$ & $-0.38 / 0$ & $-0.06 / 0$ & $-0.88 / 0$ & $-0.76 / 0$ & $1.29 / 2$ & $-0.50 / 0$ \\
\hline S7 & $0.13 / 1$ & $1.49 / 2$ & $0.51 / 1$ & $0.50 / 1$ & $-0.01 / 0$ & $0.84 / 1$ & $2.73 / 3$ & $1.17 / 2$ \\
\hline S8 & $-0.11 / 0$ & $0.64 / 1$ & $-0.04 / 0$ & $0.11 / 1$ & $-0.53 / 0$ & $0.08 / 1$ & $2.28 / 3$ & $0.30 / 1$ \\
\hline S9 & $-0.24 / 0$ & $-0.05 / 0$ & $-0.37 / 0$ & $-0.06 / 0$ & $-0.80 / 0$ & $-0.67 / 0$ & $1.22 / 2$ & $0.004 / 1$ \\
\hline $\mathrm{S} 10$ & $0.06 / 1$ & $1.26 / 2$ & $0.46 / 1$ & $0.37 / 1$ & $-0.06 / 0$ & $0.77 / 1$ & $2.66 / 3$ & $1.56 / 2$ \\
\hline S11 & $-0.47 / 0$ & $-0.39 / 0$ & $-0.73 / 0$ & $-0.44 / 0$ & $-0.75 / 0$ & $-0.63 / 0$ & $1.22 / 2$ & $-0.51 / 0$ \\
\hline $\mathrm{S} 12$ & $-0.45 / 0$ & $-0.44 / 0$ & $-0.68 / 0$ & $-0.44 / 0$ & $-0.86 / 0$ & $-0.68 / 0$ & $1.25 / 2$ & $-0.04 / 0$ \\
\hline $\mathrm{S} 13$ & $-0.22 / 0$ & $0.08 / 1$ & $-0.09 / 0$ & $-0.11 / 0$ & $-0.66 / 0$ & $-0.37 / 0$ & $1.83 / 2$ & $0.36 / 1$ \\
\hline Average & $-0.21 / 0$ & $0.29 / 1$ & $-0.06 / 0$ & $0.02 / 1$ & $-0.49 / 0$ & $-0.17 / 0$ & $1.99 / 2$ & $0.27 / 1$ \\
\hline
\end{tabular}

TABLE 6: The $E_{i}$ and RI values of heavy metals in surface sediment from TGR.

\begin{tabular}{|c|c|c|c|c|c|c|c|c|c|}
\hline \multirow{2}{*}{ Sampling sites } & \multicolumn{8}{|c|}{$E_{i}$ value of heavy metal } & \multirow{2}{*}{ RI value } \\
\hline & $\mathrm{Cr}$ & $\mathrm{Cu}$ & $\mathrm{Zn}$ & $\mathrm{Ni}$ & As & $\mathrm{Pb}$ & $\mathrm{Cd}$ & $\mathrm{Hg}$ & \\
\hline $\mathrm{S} 1$ & 2.45 & 8.90 & 1.36 & 7.92 & 12.09 & 6.87 & 146.29 & 78.54 & 272.33 \\
\hline S2 & 2.16 & 6.40 & 3.22 & 7.31 & 8.23 & 5.67 & 780.00 & 113.67 & 933.98 \\
\hline S3 & 2.67 & 9.61 & 1.33 & 8.20 & 14.51 & 6.87 & 153.71 & 56.62 & 261.72 \\
\hline S4 & 2.32 & 5.95 & 0.93 & 6.92 & 10.08 & 4.08 & 100.82 & 37.48 & 175.50 \\
\hline S5 & 3.25 & 19.94 & 2.05 & 9.48 & 14.32 & 13.18 & 279.59 & 90.56 & 441.84 \\
\hline S6 & 2.50 & 6.28 & 1.15 & 7.19 & 8.16 & 4.43 & 110.10 & 42.37 & 189.37 \\
\hline S7 & 3.28 & 21.06 & 2.14 & 10.64 & 14.87 & 13.45 & 297.84 & 135.17 & 509.08 \\
\hline S8 & 2.79 & 11.66 & 1.45 & 8.08 & 10.41 & 7.90 & 218.35 & 74.04 & 342.77 \\
\hline S9 & 2.53 & 7.26 & 1.16 & 7.20 & 8.61 & 4.71 & 105.15 & 60.15 & 203.96 \\
\hline S10 & 3.12 & 17.96 & 2.06 & 9.72 & 14.42 & 12.82 & 284.85 & 176.32 & 530.97 \\
\hline S11 & 2.17 & 5.73 & 0.90 & 5.52 & 8.93 & 4.84 & 104.54 & 42.22 & 180.38 \\
\hline S12 & 2.19 & 5.55 & 0.94 & 5.55 & 8.25 & 4.67 & 107.01 & 58.36 & 198.06 \\
\hline S13 & 2.57 & 7.92 & 1.41 & 6.96 & 9.46 & 5.78 & 159.59 & 76.89 & 277.55 \\
\hline Average & 2.61 & 10.32 & 1.55 & 7.74 & 10.95 & 7.33 & 219.06 & 80.18 & 347.50 \\
\hline
\end{tabular}

polluted" level. Next, the average $I_{\text {geo }}$ values of $\mathrm{Cr}, \mathrm{Zn}, \mathrm{As}$, and $\mathrm{Pb}$ were lower than 0 , which were ranked as "unpolluted" level. But the $I_{\text {geo }}$ values of $\mathrm{Cr}, \mathrm{Zn}$, and $\mathrm{Pb}$ in sampling sites such as S2, S5, S7, and S10 were more than 0, which were ranked as "slightly polluted" or "moderately polluted" level.

The results of the potential ecological risk level of heavy metals in sediment of TGR tributaries were shown in Table 6. Among the average $E_{i}$ values of $\mathrm{Cr}, \mathrm{Cu}, \mathrm{Zn}, \mathrm{Ni}, \mathrm{As}$, and $\mathrm{Pb}$ in sediments were $2.61,10.32,1.55,7.74,10.95$, and 7.33, respectively. The average $E_{i}$ values of these metals in all sampling sites were lower than 40 , which were ranked as slightly ecological risk level. Moreover, the average $E_{i}$ value (80.18) of $\mathrm{Hg}$ was more than 80 and lower than 160 , which was ranked as strongly ecological risk level. In fact, $\mathrm{Hg}$ pollution in $\mathrm{S} 10$ was reached at very strongly ecological risk level. The average $E_{i}$ value (219.06) of Cd was more than 160 and lower than 320 , which was reached at very strongly ecological risk level.

The average RI value of the heavy metals in sediments from TGR tributaries was 347.50, which was between 300 and 600. This indicated that the heavy metals in sediments collected from TGR tributaries exhibited strongly potential ecological risk level, especially for $\mathrm{Cd}$ and $\mathrm{Hg}$. The order of the potential ecological risk of heavy metals in surface sediment from TGR tributaries was $\mathrm{Cd}>\mathrm{Hg}>\mathrm{As}>\mathrm{Cu}>\mathrm{Ni}>\mathrm{Pb}>$ $\mathrm{Cr}>\mathrm{Zn}$, which was corresponding to not only concentration level but also ecology toxic coefficient for heavy metals.

3.5. Lead Isotopic Signatures. In order to identify potential $\mathrm{Pb}$ sources of sediment, the $\mathrm{Pb}$ isotopic compositions of sediment samples were analyzed. The results of $\mathrm{Pb}$ isotope ratios of sediment samples and other environmental sources $[8,19-21]$ were shown in Figure 3. Lead isotopic ratios in sediments from TGR tributaries ranged from 1.171 to 1.202 for ${ }^{206} \mathrm{~Pb} /{ }^{207} \mathrm{~Pb}$ and 2.459 to 2.482 for ${ }^{208} \mathrm{~Pb} /{ }^{207} \mathrm{~Pb}$, which varied with other different environmental media. The average values of $\mathrm{Pb}$ isotope ratios $\left({ }^{206} \mathrm{~Pb} /{ }^{207} \mathrm{~Pb}\right.$ and $\left.{ }^{208} \mathrm{~Pb} /{ }^{207} \mathrm{~Pb}\right)$ were 1.183 and 2.471. In fact, geochemical background $\mathrm{Pb}$ generally has 


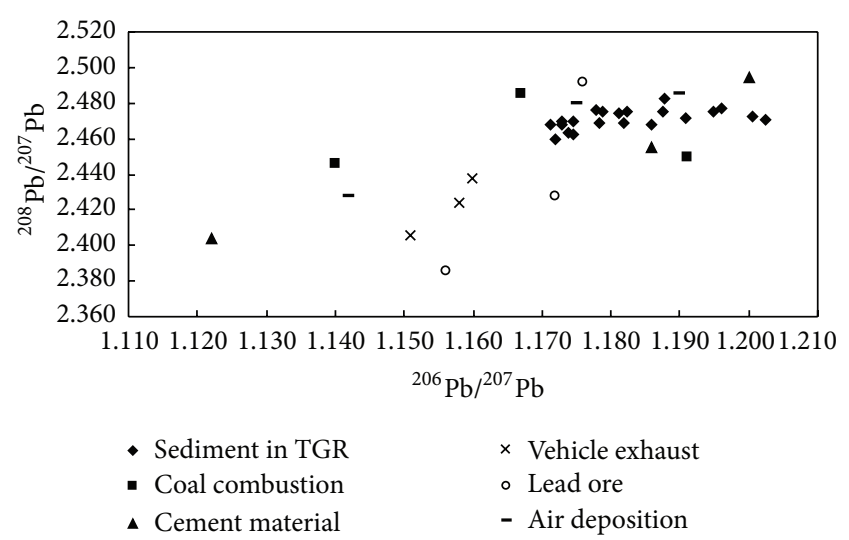

FIGURE 3: The distribution of $\mathrm{Pb}$ isotopic compositions in sediments from TGR and other environmental sources.

relatively high ${ }^{206} \mathrm{~Pb} /{ }^{207} \mathrm{~Pb}(\sim 1.200)$, while low ${ }^{206} \mathrm{~Pb} /{ }^{207} \mathrm{~Pb}$ ratios $(<1.190)$ may indicate potential anthropogenic inputs. Thus, it can be seen that ratios of ${ }^{206} \mathrm{~Pb} /{ }^{207} \mathrm{~Pb}$ in most sediments from TGR were lower than 1.200, suggesting the influence of anthropogenic inputs on TGR. In order to assess $\mathrm{Pb}$ contamination and identify potential $\mathrm{Pb}$ sources of sediments, the correlation ${ }^{206} \mathrm{~Pb} /{ }^{207} \mathrm{~Pb}$ and ${ }^{208} \mathrm{~Pb} /{ }^{207} \mathrm{~Pb}$ ratios in sediments were also analyzed. The results showed that the relationship was not obviously correlated $\left(R^{2}=0.2863\right)$, indicating that $\mathrm{Pb}$ sources of sediments were relatively complicated and cannot be simply attributed to binary mixing process of two sources [22].

The ${ }^{206} \mathrm{~Pb} /{ }^{207} \mathrm{~Pb}$ and ${ }^{208} \mathrm{~Pb} /{ }^{207} \mathrm{~Pb}$ ratios in sediments were significantly higher than those from emission from vehicle exhaust (Figure 3). This indicated that vehicle exhaust may not be the main source responsible for $\mathrm{Pb}$ pollution in this region. Another research has also confirmed that lead concentrations of atmospheric aerosols in China were decreased significantly after the leaded gasoline ban [23]. However, all $\mathrm{Pb}$ isotopic ratios in sediments were similar to those from coal combustion and cement material, indicating that these two anthropogenic sources may be the main sources for $\mathrm{Pb}$ pollution in the sediments of TGR tributaries. In fact, coal was still the important source of energy for economic and industrial development in cities around TGR. With the rapid development of large cites (Chongqing) in upstream of TGR, the building construction of sites may be producing a large number of waste materials made by cement material. In addition, the ${ }^{206} \mathrm{~Pb} /{ }^{207} \mathrm{~Pb}$ and ${ }^{208} \mathrm{~Pb} /{ }^{207} \mathrm{~Pb}$ ratios in sediments were similar to lead ores and air deposition, suggesting that these sources may be the other major sources for $\mathrm{Pb}$ pollution in the TGR. In fact, as an important transportation of heavy metals, air deposition contained the suspended particles with high $\mathrm{Pb}$ concentrations $[24,25]$. These air particles can enter into water environment and then deposit into the sediments.

\section{Conclusion}

Our investigation showed that the mean concentrations of $\mathrm{Cr}$, $\mathrm{Cu}, \mathrm{Zn}, \mathrm{Ni}$, As, $\mathrm{Pb}, \mathrm{Cd}$, and $\mathrm{Hg}$ were obviously higher than the background values of sediments and soils in China. The results of spatial distribution of heavy metals in sediments showed that heavy metals in sediments from TGR tributaries showed a similar spatial distribution, except for $\mathrm{Zn}$ and $\mathrm{Cd}$. Among the eight metals, $\mathrm{Cr}, \mathrm{Cu}, \mathrm{Zn}, \mathrm{As}$, and $\mathrm{Cd}$ showed remarkable correlation with each other. However, $\mathrm{Pb}$ showed good correlation with $\mathrm{Ni}$. The assessment by Geoaccumulation Index indicated that $\mathrm{Cr}, \mathrm{Zn}, \mathrm{As}$, and $\mathrm{Pb}$ were ranked as the unpolluted level, while $\mathrm{Cu}, \mathrm{Ni}$, and $\mathrm{Hg}$ were classified as the slightly polluted level. Cd was at moderately polluted level. The assessment by Potential Ecological Risk Index indicated that $\mathrm{Cr}, \mathrm{Cu}, \mathrm{Zn}, \mathrm{Ni}, \mathrm{As}$, and $\mathrm{Pb}$ were viewed at slightly ecological risk level. However, $\mathrm{Hg}$ was ranked as the strongly ecological and $\mathrm{Cd}$ was reached at very strongly risk level in sediments, suggesting that $\mathrm{Hg}$ and $\mathrm{Cd}$ are the predominant elements in TGR sediments. Lead isotopic ratios ranged from 1.171 to 1.202 for ${ }^{206} \mathrm{~Pb} /{ }^{207} \mathrm{~Pb}$ and 2.459 to 2.482 for ${ }^{208} \mathrm{~Pb} /{ }^{207} \mathrm{~Pb}$ in sediments from TGR tributaries and $\mathrm{Pb}$ sources in sediments were complicated (more than two sources) to identify. All $\mathrm{Pb}$ isotopic radios in sediments were similar to those from coal combustion, lead ores (the mining activities and smelting), and cement material, indicating that these anthropogenic sources may be the main sources for $\mathrm{Pb}$ pollution in the sediments of TGR tributaries.

\section{Conflict of Interests}

The authors declare that there is no conflict of interests regarding the publication of this paper.

\section{Acknowledgments}

This work was financially supported by the Major Science and Technology Program for Water Pollution Control and Treatment (Grant no. 2012ZX07104-001) China Postdoctoral Science Foundation (Grant no. 2013M530668) and the National Instrumentation Program (Grant no. 2011YQ14015009).

\section{References}

[1] B. Gao, J. Lu, H. D. Zhou, S. H. Yin, and H. Hao, "The distribution, accumulation and potential source of seldom monitored trace elements in sediments of Beijiang River, South China," Water Science \& Technology, vol. 65, no. 12, pp. 2118-2124, 2012.

[2] B. Gao, Y. K. Yu, H. D. Zhou, and J. Lu, "Accumulation and distribution characteristics of platinum group elements in roadside dusts in Beijing, China," Environmental Toxicology and Chemistry, vol. 31, no. 6, pp. 1231-1238, 2012.

[3] A. Tessier, P. G. C. Campbell, and M. Blsson, "Sequential extraction procedure for the speciation of particulate trace metals," Analytical Chemistry, vol. 51, no. 7, pp. 844-851, 1979.

[4] C. C. Ip, X. D. Li, G. Zhang, C. S. Wong, and W. L. Zhang, "Heavy metal and $\mathrm{Pb}$ isotopic compositions of aquatic organisms in the Pearl River Estuary, South China," Environmental Pollution, vol. 138, no. 3, pp. 494-504, 2005.

[5] E. Uluturhan and F. Kucuksezgin, "Heavy metal contaminants in Red Pandora (Pagellus erythrinus) tissues from the Eastern Aegean Sea, Turkey," Water Research, vol. 41, no. 6, pp. 1185-1192, 2007. 
[6] Y. Liu, H. C. Liu, and X. H. Li, "Simultaneous and precise determination of 40 trace elements in rock samples using ICPMS," Geochimica, vol. 25, no. 6, pp. 552-226, 1966 (Chinese).

[7] Z. Bing-Quan, C. Yu-Wei, and P. Jian-Hua, "Lead isotope geochemistry of the urban environment in the pearl river delta," Applied Geochemistry, vol. 16, no. 4, pp. 409-417, 2001.

[8] W. Todt, R. A. Cliff, A. Hanser, and A. W. Hofmann, "Recalibration of NBS lead standards using a ${ }^{202} \mathrm{~Pb}+{ }^{205} \mathrm{~Pb}$ double spike," Terra Nova Supplements, vol. 5, p. 396, 1993.

[9] G. Müller, "Schwermetalle in den sedimenten des Rheins-Veränderungen seitt 1971," Umschan, vol. 79, pp. 778-783, 1979.

[10] CNEMC (China National Environmental Monitoring Centre), The Background Values of Chinese Soils, Environmental Science Press of China, Beijing, China, 1990, (Chinese).

[11] L. Häkanson, "An ecological risk index for aquatic pollution control. A sedimentological approach," Water Research, vol. 14, no. 8, pp. 975-1001, 1980.

[12] Z. Q. Xu, J. S. Ni, and C. J. Zhang, "Calculation of heavy metal's toxicity coefficient in the evaluation of Potential Ecological Risk Index," Environmental Science \& Technology, vol. 31, no. 2, pp. 112-115, 2008 (Chinese).

[13] Q. H. Chi and M. C. Yan, Geochemistry of Sediments of the China Shelf Sea, Science Press, Beijing, China, 2007, (Chinese).

[14] Z. F. Yang, Y. Wang, Z. Y. Shen, J. F. Niu, and Z. W. Tang, "Distribution and speciation of heavy metals in sediments from the mainstream, tributaries, and lakes of the Yangtze River catchment of Wuhan, China," Journal of Hazardous Materials, vol. 166, no. 2-3, pp. 1186-1194, 2009.

[15] Y. X. Song, J. F. Ji, Z. F. Yang et al., "Geochemical behavior assessment and apportionment of heavy metal contaminants in the bottom sediments of lower reach of Changjiang River," Catena, vol. 85, no. 1, pp. 73-81, 2011.

[16] D. D. MacDonald, C. G. Ingersoll, and T. A. Berger, "Development and evaluation of consensus-based sediment quality guidelines for freshwater ecosystems," Archives of Environmental Contamination and Toxicology, vol. 39, no. 1, pp. 20-31, 2000.

[17] G. H. Guo, M. Lei, T. B. Chen, B. Song, and X. Y. Li, "Effect of road traffic on heavy metals in road dusts and roadside soils," Acta Scientiae Circumstantiae, vol. 28, no. 10, pp. 1937-1945, 2008 (Chinese).

[18] R. M. Harrison, R. Tilling, M. S. Callén Romero, S. Harrad, and K. Jarvis, "A study of trace metals and polycyclic aromatic hydrocarbons in the roadside environment," Atmospheric Environment, vol. 37, no. 17, pp. 2391-2402, 2003.

[19] H. Mukai, N. Furuta, T. Fujli, Y. Ambe, K. Sakamoto, and Y. Hashkmoto, "Characterization of sources of lead in the urban air of asia using ratios of stable lead isotopes," Environmental Science and Technology, vol. 27, no. 7, pp. 1347-1356, 1993.

[20] J. M. Chen, M. G. Tan, Y. L. Li et al., "A lead isotope record of Shanghai atmospheric lead emissions in total suspended particles during the period of phasing out of leaded gasoline," Atmospheric Environment, vol. 39, no. 7, pp. 1245-1253, 2005.

[21] H. Mukai, A. Tanaka, T. Fujii et al., "Regional characteristics of sulfur and lead isotope ratios in the atmosphere at several Chinese urban sites," Environmental Science and Technology, vol. 35, no. 6, pp. 1064-1071, 2001.

[22] H. F. Cheng and Y. N. Hu, "Lead (Pb) isotopic fingerprinting and its applications in lead pollution studies in China: a review," Environmental Pollution, vol. 158, no. 5, pp. 1134-1146, 2010.

[23] W. Wang, X. D. Liu, L. W. Zhao, D. F. Guo, X. D. Tian, and F. Adams, "Effectiveness of leaded petrol phase-out in Tianjin,
China based on the aerosol lead concentration and isotope abundance ratio," Science of the Total Environment, vol. 364, no. 1-3, pp. 175-187, 2006.

[24] L. D. Yu, G. F. Wang, G. H. Zhu, and R. Zhang, "Characteristics and sources of elements in atmospheric particles before and during the 2008 heating period in Beijing," Acta Scientiae Circumstantiae, vol. 30, no. 1, pp. 204-210, 2010 (Chinese).

[25] J. C. Duan and J. H. Tan, "Atmospheric heavy metals and Arsenic in China: situation, sources and control polices," Atmospheric Environment, vol. 74, pp. 93-101, 2013. 

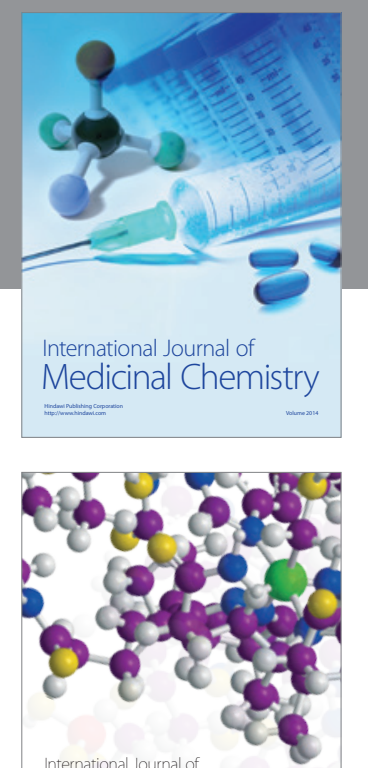

\section{Carbohydrate} Chemistry

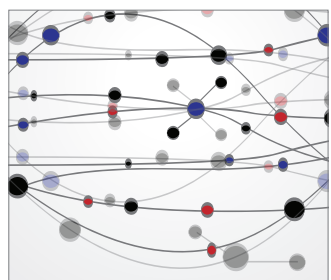

The Scientific World Journal
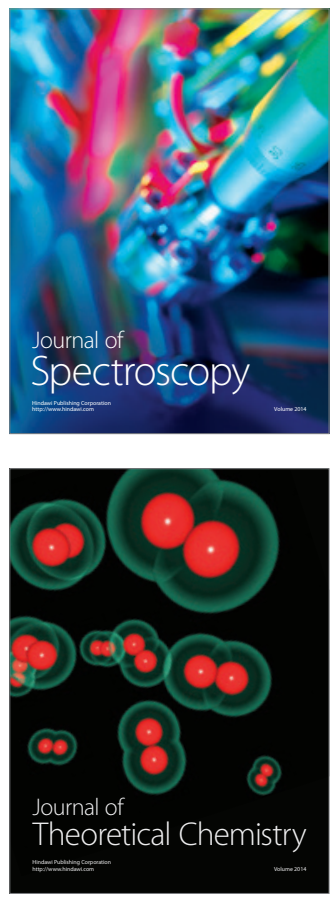
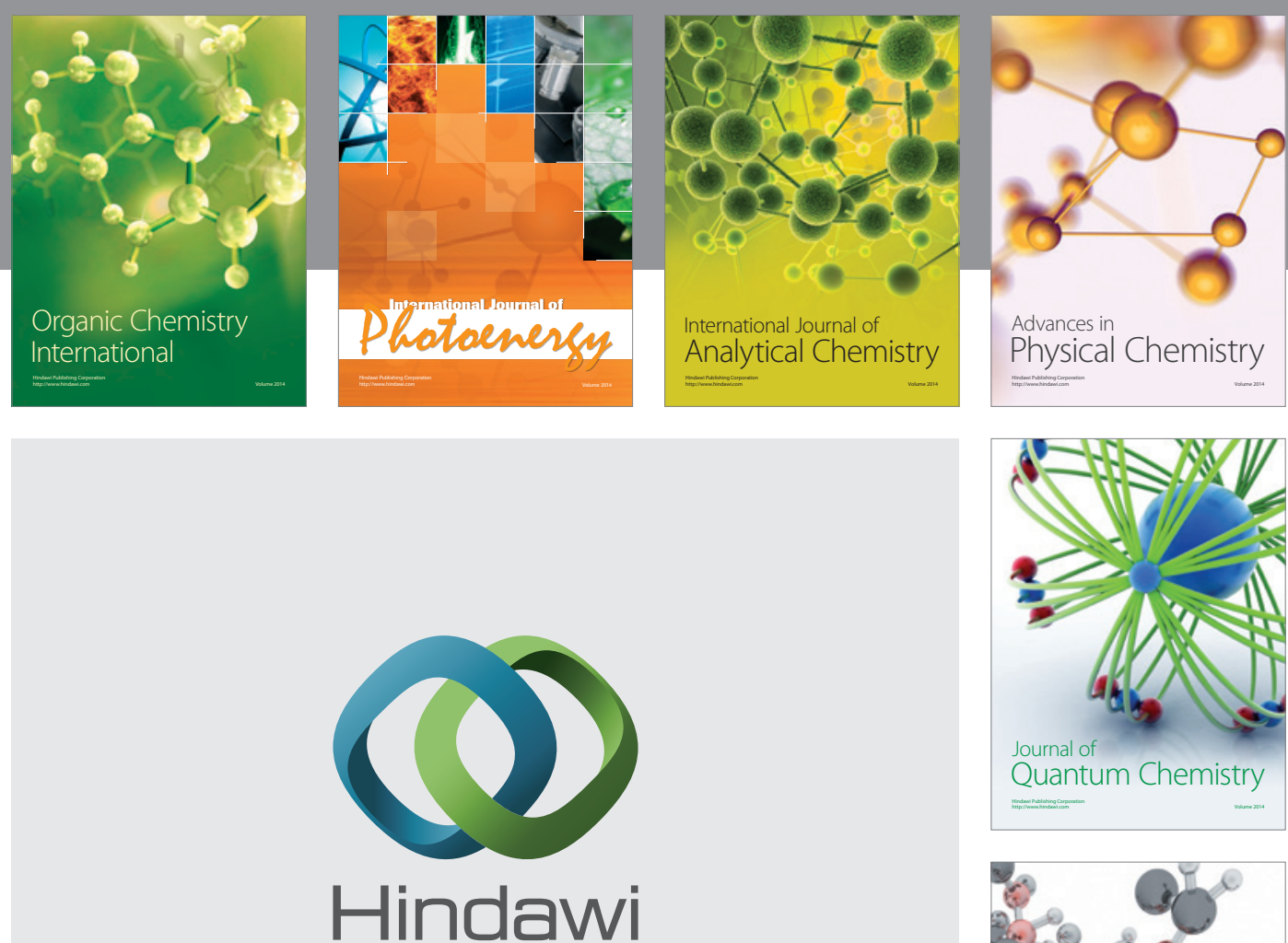

Submit your manuscripts at

http://www.hindawi.com

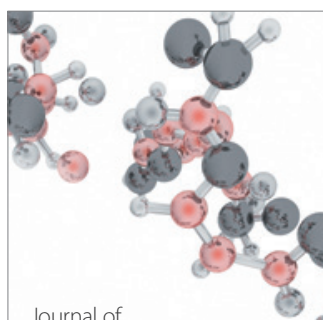

Analytical Methods

in Chemistry

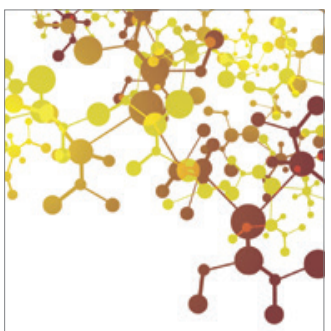

Journal of

Applied Chemistry

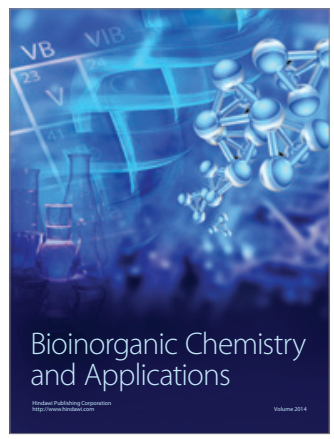

Inorganic Chemistry
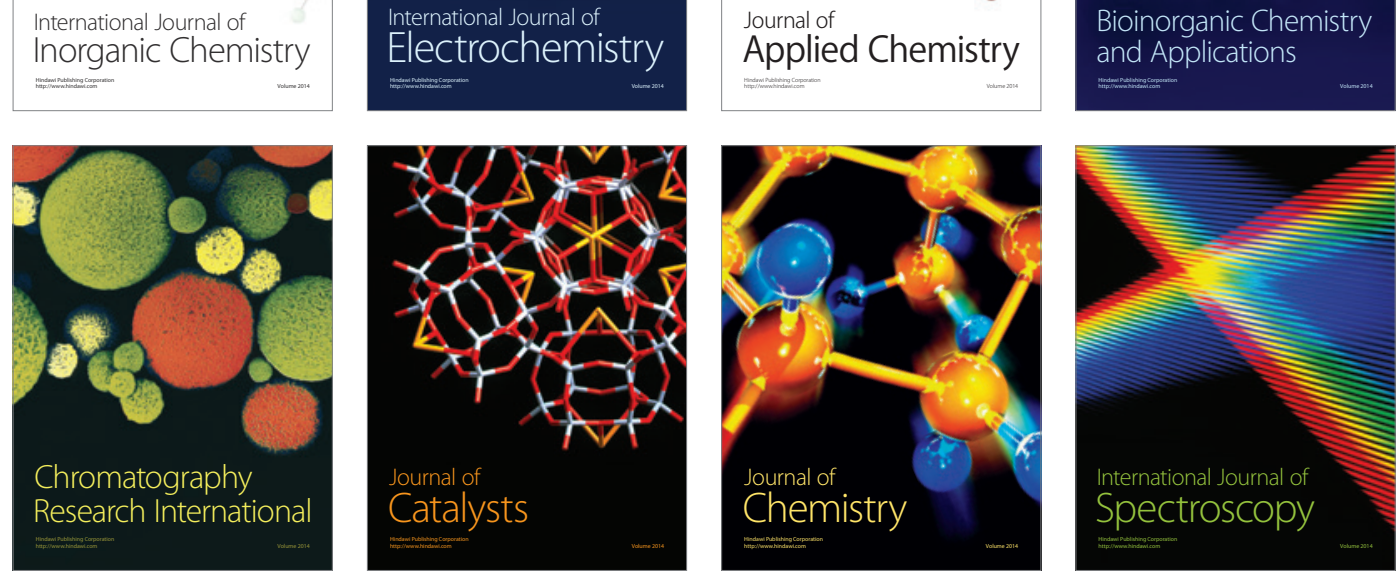